\title{
THE DETERMINATION OF THE SURVIVAL OF TRANSFUSED RED CELLS BY A METHOD OF DIFFERENTIAL HEMOLYSIS ${ }^{1}$
}

\author{
By THOMAS H. HURLEY ${ }^{2}$ aNd RUSSELL WEISMAN, JR. ${ }^{3}$ With THE TECHNICAL \\ ASSISTANCE OF ANGELA E. PASQUARIELLO
}

\author{
(From the Department of Medicine, School of Medicine, Western Reserve and University \\ Hospitals, Cleveland, Ohio.)
}

(Submitted for publication November 2, 1953; accepted December 2, 1953)

The technique of differential agglutination of red cells, introduced by Ashby (1), has been widely used to measure the life span of red cells following transfusion. The technique of differential hemolysis was investigated as a possible alternative to this method in an attempt to separate more easily the surviving donor cells from those of the recipient.

Differential hemolysis was first used by Todd and White (2) in studies on the survival of the red cells of one bull when transfused into the circulation of a second bull. Willenegger (3) employed a method of differential hemolysis to study the survival of normal human erythrocytes transfused into the circulation of normal human recipients.

Differential hemolysis is employed in the study of survival of red cells in a manner similar to differential agglutination. Compatible but antigenically distinct red cells are introduced by transfusion into the circulation of a suitable recipient. The survival of these transfused red cells can then be followed during their life span in the recipient by taking samples of blood containing the mixed cell population, eliminating the cells of the recipient by exposing the mixture to the appropriate hemolytic antiserum, and counting the remaining number of donor cells which are not subject to hemolysis. The method of differential hemolysis is different from that of differential agglutination in that hemolysins are used instead of the corresponding agglutinins in the separation of the mixed cell population. Since Anti-A and Anti-B

1 Supported in part by Grant $\mathrm{H}-1263$ (c) from the National Institutes of Health, U. S. Public Health Service.

2 Melbourne Fellow in Medicine, University Hospitals of Cleveland, Ohio. Present address, Royal Melbourne Hospital, Melbourne, Australia.

8 Research Fellow in Medicine, School of Medicine, Western Reserve University, Cleveland, Ohio. are the only isoantibodies which occur in the form of potent hemolysins the technique is limited to transfusions within the $\mathrm{ABO}$ system and, unlike the method of differential agglutination, cannot be used in studies dependent on the $M, N$, or D antigens.

The ability of the hemolytic sera employed to hemolyze all but a very small fraction of the cells of the appropriate blood group is obviously of importance if the method is to be reliable. It was found that even the most potent hemolytic antisera did not lyse all the cells in any instance, and that a small number of unhemolyzed red cells always remained. In any prospective recipient for a study of cell survival it is necessary, therefore, to determine the number of his cells per $\mathrm{mm}^{3}$. which are not hemolyzable by the hemolytic antiserum to be used in the study. This number, which corresponds to the unagglutinable or blank count in the method of differential agglutination, will be referred to as the blank count. If the method of differential hemolysis is to be reliable in the estimation of the survival of transfused cells the blank counts of any hemolytic antisera used must conform to the specifications established for satisfactory antisera in the method of differential agglutination. Accordingly, the blank count must be low. About 20,000 cells per $\mathrm{mm}^{3}$. is usually regarded as the upper limit permitted (4). Also, the blank count should not vary significantly on storage of the serum for periods of at least five months.

To assess the reliability and accuracy of the method of differential hemolysis, the survival of transfused red cells was estimated in parallel by this technique and by a standard method of differential agglutination in seven individuals. Blank counts were performed on a number of normal individuals and on patients in a general medical 
ward. In some cases these counts were repeated after an interval of some months to determine whether or not any significant change occurred. The number of group $\mathrm{O}$ cells was also estimated in known mixtures of these with either group A or group B cells.

\section{MATERIALS AND METHODS}

\section{Transfused blood}

Blood from group $\mathrm{O}$ donors was taken into a standard acid citrate dextrose solution ${ }^{4}$ and stored at $2^{\circ} \mathrm{C}$. In no instance was the duration of such storage prior to transfusion longer than 48 hours. Immediately prior to transfusion in each case the plasma was removed and, after washing the cells once in an equivalent volume of saline, this also was removed and replaced with a further volume of saline. Cross matching was performed in each case in 30 per cent bovine albumin and by means of an indirect Coombs test by standard procedures (5).

\section{Estimation of surviving donor cells}

1. Method of differential agglutination. Dried immune rabbit Anti-A, Anti-B, and Anti-M sera (Lederle) which gave satisfactorily low blank counts in each case were used in the procedure described by Ebert and Emerson (6) with only minor modification. Dilutions of whole blood were made in two ways. As described by Emerson (7), $0.1 \mathrm{ml}$. of whole blood was pipetted into $0.9 \mathrm{ml}$. of 0.85 per cent sodium chloride solution to make a 1 in 10 dilution. One-tenth $\mathrm{ml}$. of this $1 / 10$ dilution was then added to $1.9 \mathrm{ml}$. of 0.85 per cent sodium chloride solution to produce a final dilution of 1 in 200 . A final dilution of whole blood of 1 in 204 was prepared in other instances in the following manner: A sample of $0.1 \mathrm{ml}$. of whole blood was measured within the accuracy of a Folin and $\mathrm{Wu}$ pipette ${ }^{5}$ and delivered into $5.00 \mathrm{ml}$. of 0.85 per cent sodium chloride solution to produce a dilution of 1 in 51. Using an automatic glass pipette (4), which delivered approximately $0.1 \mathrm{ml}$., one volume of the red cell suspension ( 1 in 51 ) was mixed with three volumes of 0.85 per cent sodium chloride solution to produce a final dilution of 1 part of whole blood in 204 parts of sodium chloride solution. In performing blank counts the cells in 0.5 or $1.0 \mathrm{~mm}^{3}$. were counted and in counts of surviving red cells a total of 500 to 1,000 cells usually was counted on two sides of the same counting chamber. When the number of surviving cells was small, the cells in $0.5 \mathrm{~mm}^{2}$. on each side of the chamber were counted.

2. Methods in differential hemolysis. Immune human Anti-A and Anti-B sera were used. At the commencement of this study immune sera were obtained from a patient of group $O$ who had inadvertently been given 500

-Formula: Citric Acid, $0.48 \mathrm{Gm}$; Sodium Citrate, $1.82 \mathrm{Gm}$.; Dextrose, $1.47 \mathrm{Gm}$.; Water, to $100 \mathrm{ml}$.

5 Calibrated by the manufacturer to contain $0.1 \mathrm{ml}$. with the volume adjusted to a tolerance of $\pm 0.00025 \mathrm{ml}$. ml. of group A blood. Sera from this patient (DB1 and DB2) were obtained 10 and 24 days after this transfusion of incompatible blood and contained an Anti-A hemolysin capable of giving satisfactory blank counts if used undiluted. These antisera, however, proved unsatisfactory if diluted at all and could not therefore be used in the method of differential hemolysis described below in which fresh serum was added as a source of complement. More potent hemolytic antisera were obtained from the Knickerbocker Blood Bank, New York, New York. These were prepared by the immunization of group B and group A volunteers, respectively, by two subcutaneous injections of commercially prepared group A and group B specific substance given 24 hours apart. The serum of the volunteers was harvested 10 days later. All sera were stored in amounts sufficient for one determination (about $0.2 \mathrm{ml}$.) in sealed glass ampoules at $-15^{\circ} \mathrm{C}$.

a. Differential hemolysis without added fresh serum. About $1 \mathrm{ml}$. of freshly drawn venous blood was placed, without anticoagulant, onto a paraffined watch glass. A sample of $0.1 \mathrm{ml}$. of this blood, measured within the accuracy of a Folin and Wu pipette, was delivered into $5.00 \mathrm{ml}$. of 0.85 per cent sodium chloride solution to produce a final whole blood dilution of 1 in 51 . This red cell suspension was then thoroughly mixed by repeated gentle inversion. Using an automatic glass pipette which delivered approximately $0.1 \mathrm{ml}$., equal volumes of this red cell suspension and of hemolytic antiserum were pipetted into a culture tube of dimensions $10 \times 75 \mathrm{~mm}$. which was stoppered and incubated in a water bath at $37^{\circ} \mathrm{C}$. for 15 minutes.

b. Differential hemolysis with added fresh serum. The procedure as described above was modified as follows. An equal volume of the recipients fresh serum was added, by means of the same automatic glass pipette, to the suspension of red cells before the addition of the volume of hemolytic anti-serum. Thus the final dilution of the sample of blood was 1 in $153(1$ in $51 \times 3)$ in this method instead of 1 in $102(1$ in $51 \times 2)$ in the method described previously. Incubation was carried out as above for $\mathbf{1 5}$ minutes at $37^{\circ} \mathrm{C}$.

In all cases the same Folin and $\mathrm{Wu} 0.1 \mathrm{ml}$. pipettes were used in making dilutions and the same counting chamber was used in cell counts for both methods.

\section{RESULTS}

\section{Blank counts}

The number of unhemolyzed cells per $\mathrm{mm}^{3}$. of whole blood was determined in 19 individuals using the appropriate group specific antisera. At the commencement of this study no fresh serum was added to the mixture of cells and antiserum. Using this technique eight group A subjects were studied using seven antisera and one group B subject using five antisera. The blank counts obtained were satisfactory since none was more than 26,000 
TABLE I

Results of counts of unhemolyzed cells (blank counts) of individuals of group $A_{1}$ or group $B$ using antisera containing isohemolysins of the appropriate type and with the addition of fresh normal serum as a source of complement

\begin{tabular}{ccccccc}
\hline \hline Blood & $\begin{array}{c}\text { Num- } \\
\text { ber of } \\
\text { sub- } \\
\text { group }\end{array}$ & $\begin{array}{c}\text { Number } \\
\text { of hemo- } \\
\text { jytic } \\
\text { antisera } \\
\text { used }\end{array}$ & $\begin{array}{c}\text { Number } \\
\text { of blank } \\
\text { counts } \\
\text { per- } \\
\text { formed }\end{array}$ & \multicolumn{2}{c}{$\begin{array}{c}\text { Number of unhemolyzed } \\
\text { red cells/mm.' or the } \\
\text { "blank count" }\end{array}$} \\
\hline$A_{1}$ & 5 & 8 & 20 & Mean & Range \\
B & 5 & 5 & 17 & 12,200 & $2,800-16,500$
\end{tabular}

per $\mathrm{mm}^{3}$. Of 17 counts on the group A subjects twelve were less than 10,000 per $\mathrm{mm}^{3}$. Blank counts using this technique and the same antisera were repeated over a period of six months in several of these cases, and little change in their magnitude was found for a period of about five months. At this stage, however, presumably due to deterioration in the complement in this antisera, they failed to produce complete lysis and considerably higher blank counts were obtained. At the same time agglutinated masses of unhemolyzed cells were observed when making these blank counts. Prior to this time the small number of unhemolyzed cells, representing the blank count, had shown no tendency to form agglutinates. To overcome this difficulty complement, in the form of freshly drawn serum from the subject, was added to the saline suspended cells prior to the addition of the hemolytic antiserum. With suitable sera satisfactory blank counts could be obtained by this method even after complete destruction of complement in the antiserum by heating it to $56^{\circ}$ C. for 15 minutes. Reconstituted lyophilised guinea pig serum ${ }^{6}$ was also tried as a source of complement in similar experiments but proved less satisfactory because of less complete lysis of cells and a tendency for the unlysed cells to form agglutinates. No agglutinates were observed when fresh human serum was used as a source of complement.

Using this method with added fresh serum, blank counts were done on five group $A_{1}$ subjects, five group $B$ subjects and four group $A B$ sub-

- Obtained from Carworth Farms, Inc., New City, New York. These guinea pig sera, which were used in final dilutions ranging from 1 in 3 to 1 in 9 , were not absorbed with human cells before use. jects. No group $A_{2}$ subjects were studied. Eleven Anti-A sera and nine Anti-B sera were used of which eight Anti-A and five Anti-B sera proved satisfactory since the blank count was less than 30,000 red cells per $\mathrm{mm}^{3}$. The unsatisfactory sera gave blank counts in excess of 30,000 per $\mathrm{mm}^{3}$. for group A and B subjects, although all but two of them appeared to produce complete hemolysis on examination of test cells by the unaided eye. The details of blank counts obtained with the 13 sera with low blank counts are shown in Table I, and the results of blank counts on group $\mathrm{AB}$ subjects are shown in Table II.

In several instances the blank counts of subjects were repeated, using the same antisera, after varying intervals of time. These included the recipients used in red cell survival studies where blank counts were done both at the commencement and conclusion of the study. These data are shown in Table III. It can be seen that changes in the blank count are not of sufficient magnitude to interfere significantly with the accuracy of a red cell survival study. Thus a change in blank count from 13,000 per $\mathrm{mm}^{3}$. to 10,000 per $\mathrm{mm}^{3}$. would have little effect on the accuracy in the estimation of several hundred thousand group $\mathrm{O}$ cells per $\mathrm{mm}^{3}$.

TABLE II

Results of counts of unhemolyzed cells (blank counts) of four group $A B$ individuals using antisera containing $A n t i-A$ or $A$ nti- $B$ isohemolysins and with the addition of fresh normal serum as a source of complement

\begin{tabular}{|c|c|c|c|}
\hline Subject & $\begin{array}{c}\text { Blood } \\
\text { group }\end{array}$ & $\begin{array}{l}\text { Hemolytic } \\
\text { antiserum }\end{array}$ & $\underset{\substack{\text { Blank count } \\
\text { mm. }}}{\text { molls)* }}$ \\
\hline J. D. & $A_{1} B$ & $\begin{array}{l}\text { Anti-A (NYA2) } \\
\text { Anti-B (NYB1) }\end{array}$ & $\begin{array}{r}29,000 \\
333,000\end{array}$ \\
\hline E. R. & $A_{2} B$ & $\begin{array}{l}\text { Anti-A (NYA4) } \\
\text { Anti-A (NYA5) } \\
\text { Anti-B (NYB1) } \\
\text { Anti-B (NYB5) }\end{array}$ & $\begin{array}{r}1,500,000 \\
1,500,000 \\
12,200 \\
12,200\end{array}$ \\
\hline J. K. & $A_{1} B$ & $\begin{array}{l}\text { Anti-A (NYA4) } \\
\text { Anti-A (NYA2) } \\
\text { Anti-B (NYB1) } \\
\text { Anti-B (NYB4) }\end{array}$ & $\begin{array}{r}303,000 \\
279,000 \\
44,000 \\
37,600\end{array}$ \\
\hline V.S. & $A_{2} B$ & $\begin{array}{l}\text { Anti-A (NYA4) } \\
\text { Anti-B (NYB5) }\end{array}$ & $\begin{array}{r}2,760,000 \\
7,000\end{array}$ \\
\hline
\end{tabular}

* As can be seen from the blank counts obtained, either Anti-A or Anti-B sera gave almost complete hemolysis of the cells of any one individual. In all four subjects, however, only one type of antiserum was effective in this way, the antisera of the other type leaving approximately 5 to 45 per cent of the total number of cells unhemolyzed. 
TABLE III Data obtained by repeating counts of unhemolyzed cells
(blank counts) on five individuals after varying intervals of time

\begin{tabular}{|c|c|c|c|c|}
\hline $\begin{array}{l}\text { Case } \\
\text { No. }\end{array}$ & $\begin{array}{l}\text { Blood } \\
\text { group }\end{array}$ & $\begin{array}{l}\text { Hemolytic } \\
\text { antiserum }\end{array}$ & $\begin{array}{l}\text { Interval } \\
\text { in weeks }\end{array}$ & $\begin{array}{c}\text { Blank } \\
\text { count } \\
\text { cells } / \text { mimm. }^{2}\end{array}$ \\
\hline 1 & B & $\begin{array}{l}\text { Anti-B (NYB1) } \\
\text { Anti-B (NYB4) } \\
\text { Anti-B (NYB5) }\end{array}$ & $\begin{array}{r}0 \\
23 \\
48 \\
0 \\
23 \\
48 \\
0 \\
23\end{array}$ & $\begin{array}{l}15,000 \\
15,000 \\
16,500 \\
12,400 \\
11,400 \\
13,100 \\
16,500 \\
10,100\end{array}$ \\
\hline 2 & $A_{1}$ & $\begin{array}{l}\text { Anti-A (NYA2) } \\
\text { Anti-A (NYA4) } \\
\text { Anti-A (NYA5) }\end{array}$ & $\begin{array}{r}0 \\
23 \\
27 \\
0 \\
23 \\
27 \\
0 \\
23 \\
27\end{array}$ & $\begin{array}{r}8,000 \\
14,000 \\
9,000 \\
10,400 \\
10,000 \\
14,600 \\
15,000 \\
12,000 \\
7,100\end{array}$ \\
\hline 6 & $A_{1} B$ & Anti-A (NYA2) & $\begin{array}{r}0 \\
22 \\
44\end{array}$ & $\begin{array}{l}29,000 \\
12,400 \\
24,000\end{array}$ \\
\hline 7 & B & Anti-B (NYB5) & $\begin{array}{r}0 \\
11\end{array}$ & $\begin{array}{l}2,800 \\
7,000\end{array}$ \\
\hline $\begin{array}{l}\text { Normal } \\
\text { subject }\end{array}$ & B & Anti-B (NYB4) & $\begin{array}{r}0 \\
4 \\
17 \\
44 \\
0 \\
4 \\
17 \\
44 \\
0 \\
4 \\
17 \\
44\end{array}$ & $\begin{array}{r}8,100 \\
13,500 \\
10,000 \\
11,000 \\
12,500 \\
12,900 \\
13,000 \\
13,000 \\
10,000 \\
8,400 \\
9,000 \\
13,000\end{array}$ \\
\hline
\end{tabular}

\section{Counts on known cell mixtures}

Mixtures of known proportions of group $\mathrm{O}$ red cells with either group A or group B cells were made. This was done by preparing suspensions of group $\mathrm{O}$ and either group A or B cells in saline and determining their cell content by counting 2,000 to 4,000 cells. A microburette was then used to prepare a mixture of the group $O$ cells with either group A or B cells containing a known number of group $O$ cells. The samples were measured promptly to reduce to a minimum the settling of red cells within the burette. The mixtures were so prepared that the number of group $O$ cells was in the range usually encountered in performing cell survival studies. Standard techniques, as described above under methods, were used to estimate the number of group $O$ cells in these mixtures. All sera used in the hemolytic method had been stored for a period of five months and counts were performed in duplicate using two separate samples of each serum. The results are shown in Table IV. The coefficient of variation attributable to random distribution of cells in the chamber in these experiments is estimated to be about 3 per cent since approximately 1,000 cells were counted in each instance.

\section{Red cell survival studies}

The survival of transfused group $O$ red cells was studied in seven individuals using in each instance a method of differential agglutination in parallel with one or both methods of differential hemolysis. A summary of the donors, recipients, methods and sera employed is given in Table V. The results of these survival studies have been plotted in Figure 1. In Cases 1, 2, and 6 the mean of the two counts has been plotted. These were obtained from the use of two separate hemolytic antisera in each observation on the number of surviving donor cells. In Cases 1 and 2 the agreement between duplicate counts was good when using different hemolytic antisera with added complement. Of seventeen such paired observations

TABLE IV

Counts of group $O$ cells in known mixtures with either group $A$ or group $B$ cells as determined by the method of differential hemolysis with added fresh serum as a source of complement

\begin{tabular}{|c|c|c|c|}
\hline \multirow[b]{2}{*}{$\begin{array}{l}\text { Hemolytic } \\
\text { antiserum }\end{array}$} & \multicolumn{2}{|c|}{$\begin{array}{c}\text { Count of group } O \text { cells in } \\
\text { known mixture }\end{array}$} & \multirow{2}{*}{$\begin{array}{c}\text { Deviation } \\
\text { of actual } \\
\text { count from } \\
\text { estimated } \\
\text { count,* } \\
\text { per cent }\end{array}$} \\
\hline & $\begin{array}{c}\text { Estimated } \\
\text { count, } \\
10 \% / m m .8\end{array}$ & $\begin{array}{l}\text { Actual } \\
\text { count, } \\
108 / \mathrm{mm} .\end{array}$ & \\
\hline \multicolumn{4}{|c|}{ Mixture of group $O$ and group A cells } \\
\hline $\begin{array}{l}\text { Anti-A (NYA2) } \\
\text { Anti-A (NYA2) } \\
\text { Anti-A (NYA4) } \\
\text { Anti-A (NYA4) } \\
\text { Anti-A (NYA5) } \\
\text { Anti-A (NYA5) }\end{array}$ & $\begin{array}{l}0.436 \\
0.436 \\
0.436 \\
0.436 \\
0.436 \\
0.436\end{array}$ & $\begin{array}{l}0.437 \\
0.434 \\
0.437 \\
0.443 \\
0.438 \\
0.447\end{array}$ & $\begin{array}{l}+0.23 \\
-0.46 \\
+0.23 \\
+1.61 \\
+0.46 \\
+\mathbf{2} .52\end{array}$ \\
\hline \multicolumn{4}{|c|}{ Mixture of group O and group B cells } \\
\hline $\begin{array}{l}\text { Anti-B (NYB1) } \\
\text { Anti-B (NYB1) } \\
\text { Anti-B (NYB4) } \\
\text { Anti-B (NYB4) } \\
\text { Anti-B (NYB5) } \\
\text { Anti-B (NYB5) }\end{array}$ & $\begin{array}{l}0.425 \\
0.425 \\
0.425 \\
0.425 \\
0.425 \\
0.425\end{array}$ & $\begin{array}{l}0.425 \\
0.418 \\
0.452 \\
0.411 \\
0.427 \\
0.415\end{array}$ & $\begin{array}{r}0 \\
-1.64 \\
+6.35 \\
-3.29 \\
+0.47 \\
-2.35\end{array}$ \\
\hline
\end{tabular}

* The coefficient of variation is about \pm 3 per cent since approximately 1,000 red cells were counted in each observation. 
TABLE V

Details of red cell survival studies shown in Figure 1

\begin{tabular}{|c|c|c|c|c|c|c|}
\hline \multirow[b]{2}{*}{$\begin{array}{c}\text { Case } \\
\text { number }\end{array}$} & \multirow[b]{2}{*}{$\begin{array}{c}\text { Blood } \\
\text { group of } \\
\text { recipient }\end{array}$} & \multirow[b]{2}{*}{$\begin{array}{c}\text { Blood } \\
\text { group of } \\
\text { donor }\end{array}$} & \multirow[b]{2}{*}{$\begin{array}{c}\text { Antisera } \\
\text { used for } \\
\text { differential } \\
\text { agglutination }\end{array}$} & \multicolumn{2}{|c|}{ Differential hemolysis } & \multirow[b]{2}{*}{ Comments } \\
\hline & & & & $\begin{array}{c}\text { Antiserum } \\
\text { used }\end{array}$ & $\begin{array}{l}\text { Added } \\
\text { fresh } \\
\text { normal } \\
\text { serum }\end{array}$ & \\
\hline \multicolumn{7}{|c|}{ Group 1-Normal red cells transfused into normal recipients } \\
\hline 1 & B M & O N & Anti-M & $\begin{array}{l}\text { Anti-B (NYB1) } \\
\text { Anti-B (NYB4) }\end{array}$ & + & $\begin{array}{l}\text { Normal male, aged 23, was trans- } \\
\text { fused with fresh normal donor } \\
\text { blood. }\end{array}$ \\
\hline 2 & A & 0 & Anti-A & $\begin{array}{l}\text { Anti-A (DB1) } \\
\text { Anti-A (DB2) } \\
\text { Anti-A (NYA2) } \\
\text { Anti-A (NYA5) }\end{array}$ & $\begin{array}{l}0 \\
0 \\
+ \\
+\end{array}$ & $\begin{array}{l}\text { Normal male, aged } 27 \text {, was trans- } \\
\text { fused with fresh normal donor } \\
\text { blood. }\end{array}$ \\
\hline \multicolumn{7}{|c|}{ Group 2-Normal red cells transfused into patients with anemia } \\
\hline 3 & $\mathbf{A}$ & 0 & Anti-A & Anti-A (DB1) & 0 & $\begin{array}{l}\text { Normal donor blood was trans- } \\
\text { fused into a } 20 \text {-year-old female } \\
\text { who was convalescent from an } \\
\text { episode of hemolyticanemia asso- } \\
\text { ciated with moderate thrombo- } \\
\text { cytopenia. }\end{array}$ \\
\hline 4 & A & 0 & Anti-A & Anti-A (DB1) & $\mathbf{0}$ & $\begin{array}{l}\text { Normal donor blood was trans- } \\
\text { fused into a } 25 \text {-year-old female } \\
\text { suffering from atypical nonsphe- } \\
\text { rocytic hereditary hemolytic } \\
\text { anemia. Splenectomy had been } \\
\text { performed twenty months prior } \\
\text { to this study without benefit. }\end{array}$ \\
\hline 5 & A & 0 & Anti-A & Anti-A (DB1) & $\mathbf{0}$ & $\begin{array}{l}\text { Normal donor blood was trans- } \\
\text { fused into a } 67 \text {-year-old female } \\
\text { with refractory macrocytic ane- } \\
\text { mia. Her bone marrow showed } \\
\text { a megaloblastic maturation de- } \\
\text { fect but no response had been } \\
\text { obtained with usual dosage of } \\
\text { vitamin B } 12 \text {. }\end{array}$ \\
\hline \multicolumn{7}{|c|}{ Group 3-Abnormal red cells transfused into normal recipients } \\
\hline 6 & A B & 0 & Anti-A & $\begin{array}{l}\text { Anti-A (NYA2) } \\
\text { Anti-A (DB1) }\end{array}$ & $\stackrel{+}{0}$ & $\begin{array}{l}\text { Blood from a patient with typical } \\
\text { congenital methemoglobinamia } \\
\text { was transfused into a normal } \\
\text { male aged } 30 \text {. }\end{array}$ \\
\hline 7 & B & $\mathbf{O}$ & Anti-B & Anti-B (NYB5) & + & $\begin{array}{l}\text { Blood from a subject with ellip- } \\
\text { tocytosis was transfused into a } \\
60 \text {-year-old male convalescent } \\
\text { from a compound fracture of the } \\
\text { leg. }\end{array}$ \\
\hline
\end{tabular}

all but three were within twice the calculated standard deviation (Table VI) to be expected from random distribution of cells in the counting chamber. This standard deviation was calculated by taking the square root of the total number of cells counted using both antisera and multiplying by the dilution factor ( 8 ).

In Case 2, agreement between these paired observations using the method of differential hemolysis without added complement was not good. In all observations made after the sixtieth day the sera employed without added complement were found to be ineffective in hemolyzing all but a small fraction of the recipient's cells which were seen in clumps in the counting chamber when counts of the surviving donor cells were performed. A similar observation was made at about the same time and using one of the same antisera (DB1) in Case 6. In both instances the serum had been stored for a period of about six and one-half 

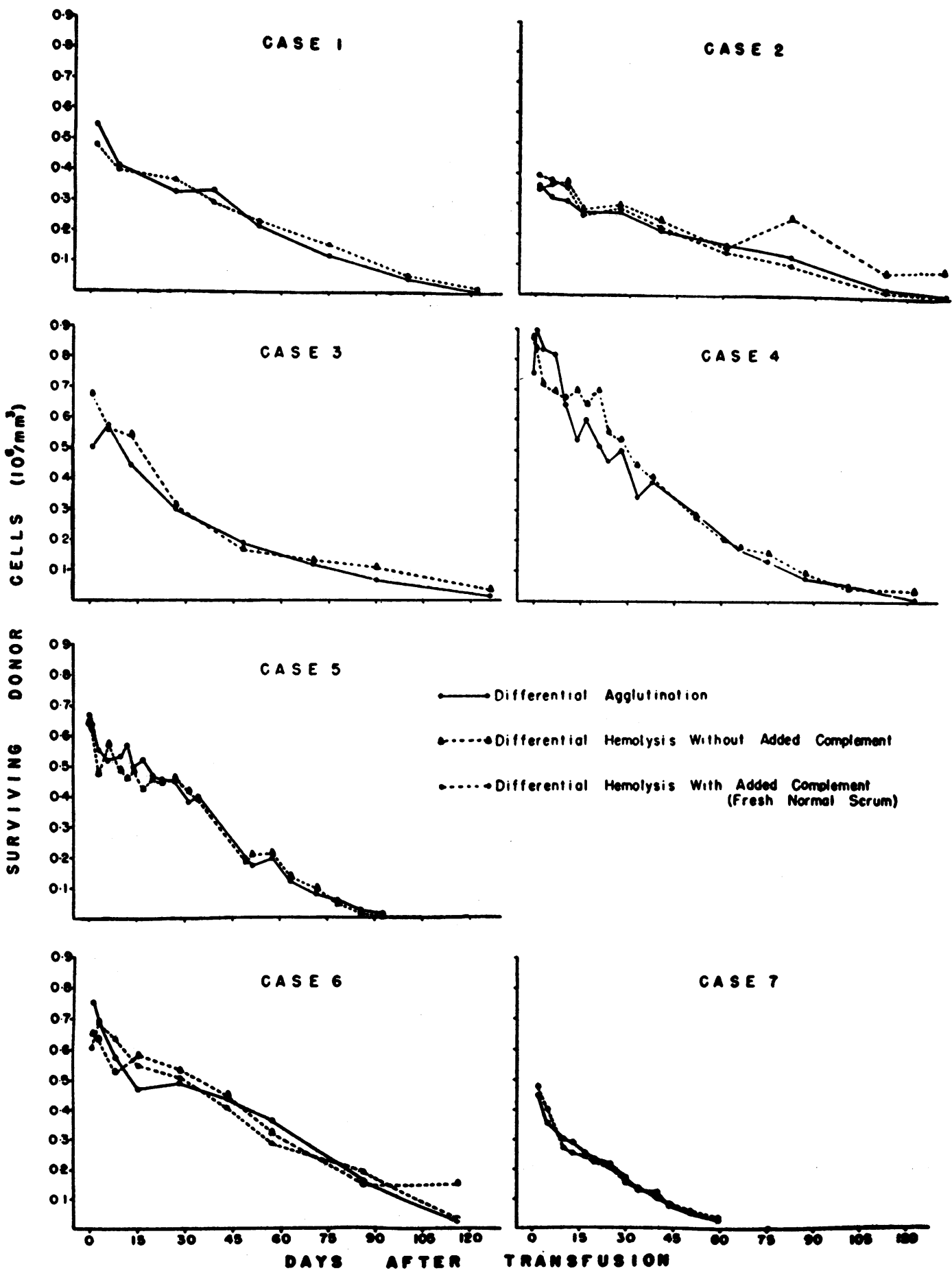

Fig. 1. The Survival of Transfused Group O Red Cells in Seven Individuals

In each case this has been estimated in parallel by the methods of differential agglutination and differential hemolysis. Results are expressed as the number of surviving donor cells present per $\mathbf{m m}^{2}$. of whole blood. 
TABLE VI

Data of parallel estimations of surviving donor cells in Cases 1 and 2 using two different hemolytic antisera in the method of differential hemolysis with the addition of fresh serum as a source of complement

\begin{tabular}{|c|c|c|c|c|}
\hline $\begin{array}{l}\text { Days after } \\
\text { transfusion }\end{array}$ & \multicolumn{2}{|c|}{$\begin{array}{l}\text { Number of surviving } \\
\text { donor cells } \\
\left(10^{\circ} / \mathrm{mm}^{3}\right)\end{array}$} & $\begin{array}{c}\text { Difference } \\
\text { between two } \\
\text { observations } \\
\left(10^{\circ} / \mathbf{m m}^{\mathrm{d}}\right)\end{array}$ & $\begin{array}{c}\text { Anticipated error } \\
(2 \mathrm{~S} . \mathrm{D} \text {.) due to } \\
\text { random distribution } \\
\text { of cells in } \\
\text { counting chamber } \\
(10 \% / \mathrm{mm} .)^{3}\end{array}$ \\
\hline \multicolumn{5}{|c|}{ Case 1} \\
\hline $\begin{array}{r}2 \\
9 \\
27 \\
38 \\
53 \\
75 \\
100 \\
122\end{array}$ & $\begin{array}{c}\text { Anti-B (NYB1) } \\
0.592 \\
0.400 \\
0.340 \\
0.333 \\
0.222 \\
0.118 \\
0.060 \\
0.014\end{array}$ & $\begin{array}{c}\text { Anti-B (NYB4) } \\
0.500 \\
0.417 \\
0.311 \\
0.335 \\
0.225 \\
0.125 \\
0.048 \\
0.014\end{array}$ & $\begin{array}{l}0.092^{*} \\
0.017 \\
0.029 \\
0.002 \\
0.003 \\
0.007 \\
0.012^{*} \\
0.000\end{array}$ & $\begin{array}{l}0.058 \\
0.041 \\
0.032 \\
0.033 \\
0.027 \\
0.013 \\
0.009 \\
0.005\end{array}$ \\
\hline \multicolumn{5}{|c|}{ Case 2} \\
\hline $\begin{array}{r}1 \\
5 \\
10 \\
15 \\
27 \\
40 \\
61 \\
82 \\
113\end{array}$ & $\begin{array}{c}\text { Anti-A (NYA5) } \\
0.408 \\
0.373 \\
0.361 \\
0.251 \\
0.277 \\
0.236 \\
0.145 \\
0.097 \\
0.023\end{array}$ & $\begin{array}{c}\text { Anti-A (NYA2) } \\
0.375 \\
0.387 \\
0.341 \\
0.280 \\
0.281 \\
0.223 \\
0.140 \\
0.101 \\
0.035\end{array}$ & $\begin{array}{l}0.033 \\
0.014 \\
0.020 \\
0.029 \\
0.004 \\
0.013 \\
0.005 \\
0.004 \\
0.012 *\end{array}$ & $\begin{array}{l}0.040 \\
0.039 \\
0.038 \\
0.030 \\
0.034 \\
0.022 \\
0.013 \\
0.012 \\
0.007\end{array}$ \\
\hline
\end{tabular}

* The difference between the parallel observations in these observations exceeds 2 S.D.

months since its collection. The loss of hemolytic activity was presumably due to a fall in the content of serum complement, but complement titrations were not performed. Also these particular Anti-A sera (DB1 and DB2) did not contain a sufficiently potent isohemolysin to be effective when diluted by the addition of fresh serum in the method of differential hemolysis with added complement. In both Cases 2 and 6 the blank count by the method of differential hemolysis without added complement finally rose to over 100,000 per $\mathrm{mm}^{3}$. at the conclusion of the studies.

Apart from the unsatisfactory agreement resulting from high blank counts in the method of differential hemolysis without added complement, the agreement between the number of surviving donor cells, as estimated by the methods of differential agglutination and differential hemolysis was good. It is also apparent that there was no systematic error involved since neither method gave consistently higher or lower readings than the other. Agreement between the methods was most satisfactory in Case 7 which was the last to be performed, a fact which may be attributable to increasing ex- perience in the use of both the methods of differential agglutination and differential hemolysis.

\section{DISCUSSION}

The results obtained demonstrate the possible applications and limitations of the method of differential hemolysis to estimate the survival of red cells following transfusion. Experience with the method of differential hemolysis in which no complement was added to the system showed that this technique was not reliable if the hemolytic antisera were stored for periods in excess of about five months. This was due to the fact that the blank counts obtainable with such sera rose after this time due presumably to the loss of hemolytic complement activity. This difficulty was overcome for potent hemolytic antisera by the addition of complement in the form of fresh serum to the system.

The method of differential hemolysis with added complement proved to be a practical and reliable method for the determination of red cell survival in the cases studied. Features which were considered satisfactory in the method included the 
following: The blank counts with potent antisera were low and compare favorably with those reported for the method of differential agglutination especially for recipients with blood of group B. The method of differential hemolysis obviated the separation of the donor cells from the agglutinated masses of recipient cells by the rather arbitrary mechanical means of centrifugation and agitation which are a feature of most methods of differential agglutination. By eliminating the clumps of agglutinated recipients cells from the counting chamber, the method of differential hemolysis also facilitated the counting of surviving donor cells. For this reason also the technique of differential hemolysis would appear to be more satisfactory for counts done by means of an automatic red cell counter.

The method of differential hemolysis permits easy separation, with a minimum of manipulation, of a population of donor's cells with a decreasing life expectancy in the circulation of the recipient. Such a technique might be used to study more closely the changes occurring with the process of aging of the red cell in vivo.

The method of differential hemolysis is limited in scope since red cells with $\mathrm{M}$ and $\mathrm{N}$ antigens cannot be studied because the antibodies to these antigens are not hemolytic.

Several observations were made in connection with the action of group specific isohemolysins. The resistance of a very small fraction of the cells to hemolysins by even the most potent antisera as represented by the blank count, is analogous to the unagglutinated red cells observed with the most potent isohemagglutinins. It is difficult, however, to explain the observation of unhemolyzed cells by means of the "saturation hypothesis" of McKerns which is the presumed mechanism of the unagglutinated cells. McKerns and Denstedt (9) postulate that unagglutinable cells become saturated with antibody before they have a chance to collide with other cells and that the complete saturation of their antigen receptors leaves none of these available for reaction with antibody fixed to other free or agglutinated cells. Another possible explanation for lack of hemolysis would be the consumption of hemolytic antibody or of complement. This, however, was evidently not the case since red cells added to a system containing this small number of unhemolyzed cells were readily hemolyzed showing that neither antibody nor complement had been exhausted. The mechanism responsible for unhemolyzed cells is not known.

The observation that fresh normal human serum proved a more satisfactory source of hemolytic complement than reconstituted lyophilised guinea pig serum in conjunction with the action of isohemolysins on the cells of the appropriate blood group was unexpected. In other reactions involving complement, guinea pig serum is found to be more effective than normal human serum because of the higher complement titre of the former.

Finally, the observation that the great majority of the red cells of a group $A B$ individual were susceptible to hemolysis by either Anti-A serum or Anti-B serum but not by both was interesting. The fact that 5 to 45 per cent of all the cells were not hemolyzed by one type of antiserum suggests an unequal distribution of either the $\mathrm{A}$ or $\mathrm{B}$ antigen on the cells of these group AB subjects. However, more evidence is needed to support this hypothesis.

The survival of normal red cells transfused into normal recipients showed a life span of these cells of about 120 days-a result which is in agreement with previous similar studies. The normal life span of the red cells from a patient with congenital methemoglobinemia and the decreased life span of elliptocytes in the circulations of normal recipients are also of some interest.

\section{SUMMARY}

1. A reliable technique for the estimation of the life span of transfused group $O$ cells is described employing a method of differential hemolysis.

2. If potent immune human antisera were used and fresh serum added as a source of complement, blank counts obtained with this technique compared very favorably with those obtained using the technique of differential agglutination.

3. Using this technique with added fresh serum blank counts in individuals did not vary significantly with storage of the antisera at $-15^{\circ} \mathrm{C}$. for periods up to 27 weeks.

4. Counts of group $O$ red cells in mixtures of known proportion with red cells of either group 
A or group B demonstrated the accuracy and reliability of the technique in the separation of such mixed red cell populations.

5. The survival of transfused red cells in seven recipients was estimated in parallel by techniques of differential agglutination and differential hemolysis. Satisfactory agreement between the two methods was obtained provided fresh serum was added to the mixture of cells and hemolytic antiserum to insure the presence of adequate amounts of complement in the mixture.

6. The advantages and possible application of the technique to the closer study of the changes occurring in the in vivo aging of red cells is discussed.

7. Some observations have been made on the actions of isohemolysins.

\section{REFERENCES}

1. Ashby, W., The determination of the length of life of the transfused blood corpuscles in man. J. Exper. Med., 1919, 29, 267.
2. Todd, C., and White, R. G., On the fate of the red blood corpuscles when injected into the circulation of an animal of the same species; with a new method for the determination of the total volume of blood. Proc. Roy. Soc., London, s. B., 1911, 84, 255.

3. Willenegger, H., Das Schicksal transfundierter Erythrocyten. Helvet. med. acta, 1942, 9, 15.

4. Mollison, P. L., Blood Transfusion in Clinical Medicine. Oxford, Blackwell, 1951.

5. Dacie, J. V., Practical Haematology. London, J. and A. Churchill Ltd., 1950.

6. Ebert, R. V., and Emerson, C. P., Jr., A clinical study of transfusion reactions: The hemolytic effect of group-O blood and pooled plasma containing incompatible isoagglutinins. J. Clin. Invest., 1946, $25,627$.

7. Emerson, C. P., Personal communication.

8. Ham, T. H., ed., A Syllabus of Laboratory Examinations in Clinical Diagnosis. Critical evaluation of laboratory procedures in the study of the patient. Cambridge, Harvard University Press, 1950, p. 462.

9. McKerns, K. W., and Denstedt, O. F., Free-cell phenomen in iso-haemagglutination. Canad. J. Research, 1950, Section $E 28,152$.

\section{SPECIAL NOTICE TO SUBSCRIBERS}

Post Offices will no longer forward the Journal when you move.

Please notify The Journal of Clinical Investigation, Business Office, 622 West 168th Street, New York 32, N. Y. at once when you have a change of address, and do not omit the zone number if there is one. 